\title{
EVALUASI KONDISI KERUSAKAN BANGUNAN PENGENDALI LAHAR DI SUNGAI KRASAK
}

\author{
Cahyo Dita Saputro*1 \\ ${ }^{1}$ Dosen//Teknik Sipil/Universitas Teknologi Yogyakarta \\ Korespondensi: cahyoditastmt@gmail.com
}

\begin{abstract}
The sabo dam located in the Krasak river area, which loads Mount Merapi eruptions, has been built more than 20 years old. This circumstance certainly affects the physical condition and function of the 23 sabos. Therefore, it is valuable to do a research which focuses on the damage sabo building to find out the necessary maintenance to take, so that the sabo building can be functioned properly. The method of the data collection is direct observation to the location. The results of the study indicate that 22 buildings are still in good category and 1 building is in a moderately damaged condition.
\end{abstract}

Keywords: Mount Merapi, physical condition, sabo

\section{PENDAHULUAN}

Indonesia merupakan Negara dengan jumlah gunung berapi yang cukup banyak, yaitu sebanyak 127 gunung berapi. Hal ini merupakan sebuah keuntungan karena sumber material alam yang melimpah dapat menjadi mata pencaharian masyarakat yang berada di sekitar gunung berapi. Namun demikian hal tersebut juga berbanding lurus dengan resiko yang mengancam masyarakat yang tinggal di sekitar gunung berapi tersebut. Adanya gunung berapi tentu akan menimbulkan potensi bencana alam seperti banjir lahar dingin yang timbul setelah terjadi erupsi pada gunung berapi tersebut.

Salah satu gunung berapi yang hingga saat ini masih sangat aktif adalah Gunung Merapi yang berada di Daerah Istimewa Yogyakarta. Secara letak geografis Gunung berapi berbatasan dengan Kabupaten Sleman, Kabupaten Magelang, dan Kabupaten Boyolali. Oleh karena itu terdapat potensi bencana banjir lahar yang tentunya akan menimbulkan kerusakan pada daerah sekitar sungai yang dilalui. Aliran lahar dingin yang disertai material pasir dan batuan, maupun tanah yang longsor akan menjadi aliran debris (debris flow) yang dapat menimbulkan kerusakan lebih parah dari banjir biasa [1].

Salah satu upaya untuk menanggulangi efek kerusakan yang disebabkan oleh lahar dingin dari Gunung Merapi, pada tahun 1969 para ahli dari Jepang membuat bangunan pengendali sedimen atau dikenal dengan Bangunan Sabo pada ruas sungai yang berpotensi dilalui banjir lahar dingin. Dengan adanya bangunan pengendali sedimen ini diharapkan dapat menahan laju material yang terbawa oleh lahar dingin sehingga akan meminimalisir kerusakan di sekitar sungai.

Bangunan pengendali sedimen yang telah berumur lebih dari 30 tahun tentunya memerlukan perhatian khusus mengenai kondisi fisik maupun fungsi layan dari bangunan tersebut. Mengingat aktivitas terakhir Gunung Merapi pada tahun 2010 silam ternyata menimbulkan kerusakan yang cukup parah karena banyak bangunan Sabo yang sudah tidak layak fungsi.

Berdasarkan data dari Balai Besar Wilayah Sungai Serayu-Opak, tercatat ada 254 bangunan Sabo yang tersebar pada 15 sungai (lihat Tabel 1).

Berdasarkan informasi yang ada sungai Krasak merupakan salah satu sungai yang terkena dampak yang cukup besar dari lahar dingin gunung Merapi. Melihat kondisi yang ada saat ini, dapat diasumsikan bahwa kondisi bangunan Sabo yang ada di wilayah Gunung Merapi telah mengalami penurunan fungi dan kondisi fisik. Untuk memastikan kondisi dan kelayakan fungsi bangunan Sabo tersebut maka perlu adanya inventarisasi dan evaluasi kinerja pada bangunan-bangunan Sabo yang ada di 
wilayah Gunung Merapi sehingga bangunan dapat berfungsi maksimal saat terjadi bencana banjir lahar dingin.

Tabel 1. Jumlah bangunan sabo wilayah Gunung Merapi [5]

\begin{tabular}{l|l|c}
\hline No. & \multicolumn{1}{|c|}{ Sungai } & Jumlah Sabo \\
\hline 1 & Apu & 5 \\
\hline 2 & Pabelan & 19 \\
\hline 3 & Trising & 6 \\
\hline 4 & Senowo & 8 \\
\hline 5 & Lamat & 14 \\
\hline 6 & Blongkeng & 17 \\
\hline 7 & Putih & 24 \\
\hline 8 & Batang & 10 \\
\hline 9 & Bebeng & 13 \\
\hline 10 & Krasak & 23 \\
\hline 11 & Boyong & 56 \\
\hline 12 & Kuning & 6 \\
\hline 13 & Opak & 23 \\
\hline 14 & Gendol & 12 \\
\hline 15 & Woro & \\
\hline
\end{tabular}

\section{TINJAUAN PUSTAKA}

\subsection{Bangunan Pengendali Lahar (Sabo)}

Sabo adalah istilah yang berasal dari Jepang yang terdiri dari kata SA yang berarti pasir (sand) dan BO yang berarti penanggulangan (prevention). Jadi kata $\mathrm{SABO}$ mempunyai arti: Penanggulangan bencana yang diakibatkan pergerakan tanah atau sedimen yang dibawa oleh aliran air. Kata Sabo diusulkan oleh seorang ahli konservasi dari Amerika Serikat, yang bernama Dr. Lowdermilk pada kunjungannya ke Jepang pada tahun 1951 [2].

Di Indonesia, teknik sabo diperkenalkan pertama untuk kali oleh seorang tenaga ahli Jepang, Mr. Tomoaki Yokota pada tahun 1970, untuk menangani masalah banjir lahar di daerah vulkanik, yaitu Gunung Merapi, Gunung Kelud dan Gunung Agung. Lalu di Gunung Semeru dan Gunung Galunggung yang meletus kemudian. Di samping itu juga untuk menangani masalah erosi dan sedimentasi di daerah non-vulkanik di beberapa daerah di luar Jawa. Secara umum sabo dapat berfungsi untuk berbagai keperluan, seperti:

1. Melindungi manusia dan tempat tinggal beserta harta kekayaan mereka dari gangguan bencana alam yang diakibatkan oleh erosi dan aliran sedimen.

2. Memelihara kelestarian alam dan lingkungannya

3. Melindungi daerah perkotaan, pedesaan serta bangunan bangunan dan fasilitas umum dari bencana yang diakibatkan oleh aliran sedimen.

4. Dapat membantu pegembangan daerah melalui pemanfaatan bangunan sabo secara serba guna.

Di Indonesia, sabo telah diterapkan pada berbagai keperluan, seperti:

1. Pengendalian lahar akibat letusan gunungapi.

2. Pengendalian erosi di hutan dan daerah-daerah pertanian.

3. Pencegahan terhadap longsoran atau tanah runtuh.

4. Pencegahan erosi yang terjadi di pantai atau abrasi yang disebabkan oleh gelombang dan atau arus laut.

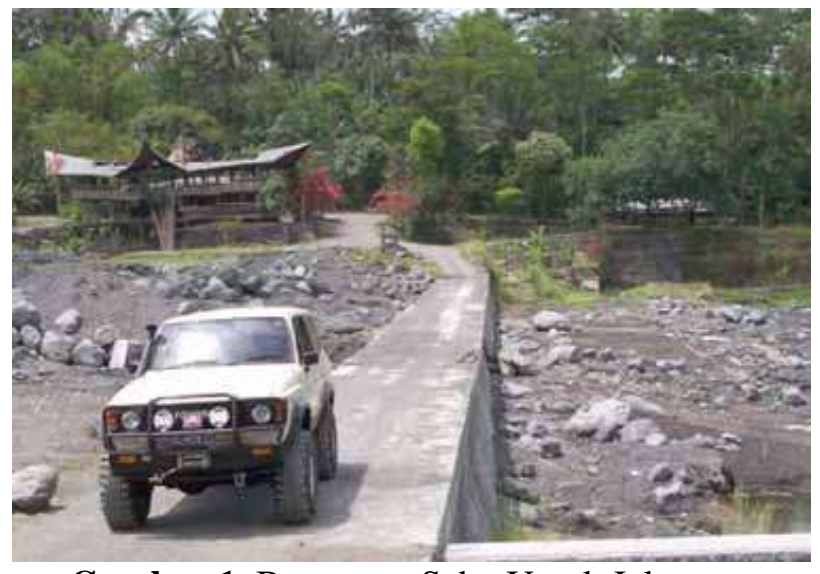

Gambar 1. Bangunan Sabo Untuk Jalan Penyeberangan

\subsection{Lingkup Kegiatan OP Prasarana Pengendali Lahar dan Sedimen}

Mengetahui lingkup kegiatan OP merupakan hal yang penting dalam penyusunan AKNOP. Lingkup kegiatan OP untuk prasarana pengendali lahar dan sedimen dapat dilihat pada Tabel 1. Dalam tabel dapat dilihat bahwa lingkup kegiatan OP prasarana pengendali lahar dan sedimen sama. Kesamaan lingkup kegiatan ini disebabkan jenis infrastruktur untuk keduanya sama. Lingkup kegiatan yang tercantum pada tabel telah diselarasakan dengan Draft Kegiatan Operasi dan 
Pemeliharaan Prasarana Pengendali Lahar dan Pengendali Sedimen [3].

Kegiatan operasi dan pemeliharaan adalah hal yang penting dilakukan pasca pelaksanaan pembangunan sebuah bangunan. Hal ini sangat berpengaruh terhadap umur layan dan kondisi fungsi dari bangunan tersebut. Kegiatan operasi dan pemeliharaan bangunan pengendali lahar (sabo) sesuai dengan pedoman kegiatan OP yang diterbitkan oleh Direktorat Jenderal Sumber Daya Air. (Tabel 2)

Tabel 2. Lingkup kegiatan OP prasarana pengendali lahar dan sedimen [3]

\begin{tabular}{|c|c|c|}
\hline \multirow{2}{*}{$\begin{array}{c}\text { Jenis } \\
\text { Kegiata } \\
\text { n }\end{array}$} & \multicolumn{2}{|c|}{ Lingkup Kegiatan OP } \\
\hline & $\begin{array}{c}\text { Prasarana } \\
\text { Pengendali Lahar }\end{array}$ & $\begin{array}{c}\text { Prasarana } \\
\text { Pengendali } \\
\text { Sedimen }\end{array}$ \\
\hline \multirow[t]{7}{*}{ Operasi } & $\begin{array}{l}\text { 1. Inventarisasi } \\
\text { dan } \\
\text { pengumpulan } \\
\text { data }\end{array}$ & $\begin{array}{l}\text { 1. Inventarisasi } \\
\text { dan } \\
\text { pengumpula } \\
\mathrm{n} \text { data }\end{array}$ \\
\hline & 2. Inspeksi rutin & $\begin{array}{l}\text { 2. Inspeksi } \\
\text { rutin }\end{array}$ \\
\hline & 3. Penelusuran & 3. Penelusuran \\
\hline & $\begin{array}{l}\text { 4. Identifikasi dan } \\
\text { analisis tingkat } \\
\text { kerusakan }\end{array}$ & $\begin{array}{l}\text { 4. Identifikasi } \\
\text { dan analisis } \\
\text { tingkat } \\
\text { kerusakan }\end{array}$ \\
\hline & $\begin{array}{l}\text { 5. Penyusunan } \\
\text { rencana } \\
\text { anggaran biaya }\end{array}$ & $\begin{array}{ll}\text { 5. } & \text { Penyusunan } \\
\text { rencana } \\
\text { anggaran } \\
\text { biaya } \\
\end{array}$ \\
\hline & \begin{tabular}{|ll}
6. & $\begin{array}{l}\text { Pengaturan } \\
\text { penggunaan }\end{array}$ \\
\end{tabular} & $\begin{array}{ll}\text { 6. } & \text { Pengaturan } \\
\text { penggunaan }\end{array}$ \\
\hline & 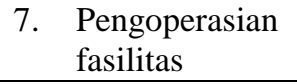 & $\begin{array}{l}\text { 7. Pengoperasi } \\
\text { an fasilitas }\end{array}$ \\
\hline \multirow[t]{3}{*}{$\begin{array}{l}\text { Pemeli } \\
\text { haraan }\end{array}$} & $\begin{array}{l}\text { 1. Pemeliharaan } \\
\text { preventif }\end{array}$ & $\begin{array}{l}\text { 1. Pemeliharaan } \\
\text { preventif }\end{array}$ \\
\hline & $\begin{array}{l}\text { 2. Pemeliharaan } \\
\text { korektif } \\
\end{array}$ & $\begin{array}{l}\text { 2. Pemeliharaan } \\
\text { korektif }\end{array}$ \\
\hline & $\begin{array}{l}\text { 3. Pemelihraan } \\
\text { rehabilitatif }\end{array}$ & $\begin{array}{l}\text { 3. Pemelihraan } \\
\text { rehabilitatif }\end{array}$ \\
\hline
\end{tabular}

\subsection{Pengoperasian fasilitas}

Peraturan pengoperasian fasilitas prasarana pengendali lahar dibuat untuk mencegah terjadinya kegiatan pengoperasian prasarana yang dapat merusak prasarana. Pengoperasian fasilitas sekurang-kurangnya berlangsung selama setahun. Contoh lingkup pengoperasian adalah:

1. Pengoperasian pintu pengambilan air.
2. Pengoperasian peralatan pemantau lahar.

\subsection{Tahap Inventarisasi dan Pengumpulan Data}

Pada tahapan inventarisasi dan pengumpulan data, kegiatan dini diimaksudkan untuk mendeapatkan data-data tentang riwayat dibangun dan rehabilitasi yang pernah dilakukan, sehingga dapat diketahui umur bangunan yang sebenarnya serta mempermudah saat inspeksi ke lapangan.

\subsection{Tahap Inspeksi dan Penelusuran}

Tahap selanjutnya yaitu inspeksi dan penelusuran di lapangan untuk mengambil data aktual kondisi Sabo terkini, sehingga dapat dilakukan identifikasi dan analisis kerusakan bangunan. Inspeksi dan penelusuran yang ditinjau meliputi 28 unsur yang tergolong menjadi bagian kondisi sekitar sungai, dam utama, apron, dan sub dam. Berdasarkan kelompok bagian-bagian dari objek selanjutnya dilakukan pembobotan untuk mengklasifikasikan nilai pengaruh dari bagianbagian yang ditinjau terhadap kondisi kerusakan yang terjadi. Nilai pembobotan bagian-bagian objek penelitian dapat dilihat pada Tabel 3 .

Tabel 3. Klasifikasi objek penelitian berdasarkan bobot [5]

\begin{tabular}{|c|c|}
\hline Objek Penilaian & Bobot \\
\hline A. Kondisi Sekitar & \multirow{8}{*}{$20 \%$} \\
\hline 1. Jalan masuk ke lokasi & \\
\hline 2. Tumbuh rumput/ semak belukar & \\
\hline 3. Marka/ portal jalan dan jembatan & \\
\hline 4. Pintu pengambilan air & \\
\hline 5. Peralatan pemantau lahar & \\
\hline 6. Lubang slit/ konduit & \\
\hline 7. Sedimentasi di sabo dam & \\
\hline B. Kondisi Sedimen & \multirow{3}{*}{$40 \%$} \\
\hline 8. Sedimentasi ruas sungai & \\
\hline 9. Penambangan di sabo dam & \\
\hline C. Dam Utama & \multirow{9}{*}{$15 \%$} \\
\hline 10. Gerusan pondasi dam & \\
\hline 11. Abrasi di tubuh dam & \\
\hline 12. Selimut tubuh dam terkelupas & \\
\hline 13. Retakan di tubuh dam & \\
\hline 14. Rembesan di tubuh dam & \\
\hline 15. Sayap dam & \\
\hline 16. Lubang slit atau konduit dam & \\
\hline 17. Pelindung (buffer fill) dam & \\
\hline
\end{tabular}




\begin{tabular}{|c|c|}
\hline Objek Penilaian & Bobot \\
\hline 18. Tebing sungai di abutmen dam & \\
\hline E. Apron & \multirow{3}{*}{$12,5 \%$} \\
\hline 19. Kondisi lantai & \\
\hline 20. Kondisi dinding & \\
\hline F.Subdam & \multirow{10}{*}{$12,5 \%$} \\
\hline 21. Gerusan pondasi subdam & \\
\hline 22. Abrasi di tubuh subdam & \\
\hline 23. Selimut tubuh subdam & \\
\hline terkelupas & \\
\hline 24. Retakan di tubuh subdam & \\
\hline 25. Rembesan di tubuh subdam & \\
\hline 26. Sayap subdam & \\
\hline 27. Pelindung (buffer fill) subdam & \\
\hline 28. Tebing sungai di abutmen & \\
\hline
\end{tabular}

\section{METODE PENELITIAN}

Penelitian dilakukan pada bangunan Sabo yang tersebar di wilayah sungai Krasak sebanyak 23 bangunan. Tahap pertama yang dilakukan adalah penyusunan instrument dan daftar checklist formulir isian untuk survey. Penilaian kinerja bangunan sabo dam merupakan proses rangkaian kegiatan pengumpulan informasi yang bersifat teknis untuk mengetahui dan menilai kondisi dan prasarana sabo dam berdasarkan kriteria dan batasan - batasan terukur. Penilaian kinerja bangunan sabo meliputi kegiatan inventarisasi dan pengumpulan data, inspeksi dan penelusuran, identifikasi dan analisis tingkat kerusakan. Proses penilaian kondisi tingkat kerusakan bangunan sabo dam dilakukan dengan pemberian skor kondisi dengan nilai 0 untuk kondisi terburuk (rusak total) sampai 5 untuk kondisi terbaik. Dari hasil pemberian skor tersebut kemudian digunakan sebagai identifikasi dan analisis tingkat kerusakan pada setiap bangunan sabo dam. Hasil identifikasi dan analisis inilah yang digunakan sebagai dasar dalam penentuan kegiatan pemeliharaan bangunan sabo dam. Rekomendasi pemeliharaan bangunan sabo ditetapkan berdasarkan parameter sebagai berikut:

a. Kondisi baik, jika tingkat kerusakan masih dibawah $10 \%$.

b. Kondisi rusak ringan, jika tingkat kerusakan $10 \%$ sampai dengan di bawah $20 \%$.

c. Kondisi rusak sedang, jika tingkat kerusakan $20 \%$ sampai dengan di bawah $40 \%$. d. Kondisi rusak berat, jika tingkat kerusakan lebih atau sama dengan 40 $\%$.

Dimana:

Nilai $0=$ Kondisi bagian bangunan yang ditinjau sudah rusak berat dan sulit diidentifikasi.

Nilai $1=$ Kondisi bagian bangunan yang ditinjau sudah rusak berat tapi masih dapat diidentifikasi.

Nilai $2=$ Kondisi bagian bangunan yang ditinjau rusak sedang, masih dapat diidentifikasi, tapi sudah tidak terlalu berfungsi dengan baik.

Nilai $3=$ Kondisi bagian bangunan yang ditinjau rusak sedang, masih dapat diidentifikasi, dan masih berfungsi dengan baik.

Nilai $4=$ Kondisi bagian bangunan yang ditinjau rusak ringan, masih dapat diidentifikasi, dan masih berfungsi dengan baik.

Nilai $5=$ Kondisi bagian bangunan yang ditinjau masih dalam kondisi baik dan masih berfungsi dengan baik.

Lingkup kegiatan penilaian kinerja dan fungsi bangunan Sabo di Sungai Krasak diuraikan menjadi tiga tahapan, yaitu tahap identifikasi masalah, tahap pengumpulan data, tahap analisis data, dan tahap perencanaan kegiatan OP bangunan Sabo.

Identifikasi masalah penting dilakukan untuk memprediksi, permasalahan yang mungkin terjadi, baik teknis maupun non teknis, sejauh mungkin. Tahap Identifikasi dan analisis tingkat kerusakan merupakan tindak lanjut hasil penelusuran. Hasil penilaian kondisi bangunan kemudian dimasukkan kedalam formulir identifikasi dan analisis tingkat kerusakan. Formulir identifikasi sesuai klasifikasi pada Tabel 2 dan analisis tingkat kerusakan. kemudian dihitung total skor hasil inspeksi, total item kondisi bangunan, total skor terbesar dan total skor seluruh item (unsur) seperti uraian berikut:

$$
\left(1-\frac{a}{n}\right) \times \frac{1}{(c / d)} \times 100
$$

Dimana:

$\mathrm{a}=$ Total skor hasil inspeks

$\mathrm{b}=$ Total item kondisi bangunan 
$\mathrm{n}=$ Total item kondisi bangunan

$\mathrm{c}=$ Total skor terbesar

$\mathrm{d}=$ Total skor seluruh item

Data-data yang diperlukan untuk kegiatan penilaian kinerja dan fungsi bangunan Sabo adalah:

a. Data peta topografi, geometri sungai, dan data geologi diperoleh dari PPK Pengendalian Lahar Gunung Merapi Yogyakarta.

b. Data gambar shop drawing atau as build drawing bangunan Sabo yang diperoleh dari PPK Pengendalian Lahar Gunung Merapi Yogyakarta dan PPK Operasi dan Pemeliharaan BBWS Serayu-Opak.

c. Data kondisi fisik dan fungsi layan bangunan sabo terbaru yang diperoleh dari survey lapangan.

Kegiatan penilaian kinerja berdasarkan instrumen bangunan Sabo di Sungai Krasak ini difokuskan pada kondisi fisik dan fungsi layan terhadap tampungan sedimen yang menjadi fungsi utama dari bangunan Sabo. Adapun langkah-langkah kegiatan penilaian Sabo antara lain:

a. Mengumpulkan data-data sekunder.

b. Menyusun draft tabel survey kerusakan bangunan Sabo.

c. Melakukan survey kerusakan dan fungsi layan bangunan Sabo.

d. Menganalisis data hasil survey, sehingga dapat diketahui angka kinerja dan fungsi bangunan.

Penilaian kinerja dan fungsi bangunan selanjutnya digunakan untuk menyusun prioritas Operasi dan Pemeliharaan terhadap bangunan tersebut, sehingga diharapkan bangunan dapat berfungsi dengan maksimal saat terjadi banjir lahar dingin.

\section{HASIL DAN PEMBAHASAN}

Tahap selanjutnya dilakukan analisis penilaian kerusakan bangunan sabo berdasarkan data nomenklatur dan tipe sabo yang tersebar di sungai Krasak yang dapat dilihat pada Tabel 4. Dari data tersebut selanjutnya dilakukan survey untuk mengetahui kondisi kerusakan pada masing-masing bangunan sabo.
Tabel 4. Daftar bangunan Sabo Sungai Krasak

\begin{tabular}{l|l|l}
\hline No & \multicolumn{1}{|c|}{ Nama } & \multicolumn{1}{|c}{ Tipe } \\
\hline 1 & KR-D5 (Tunggul Arum) & Closed-type \\
\hline 2 & BD RD1 & Open-type (Conduit) \\
\hline 3 & KR-D3 (Gondoarum) & Open-type (Silt) \\
\hline 4 & KR-C (Gedoyo) & Closed-type \\
\hline 5 & KR-C (Kembang) & Closed-type \\
\hline 6 & KR-C (Kranggan) & Open-type (Conduit) \\
\hline 7 & KR-C3 (Kranggan) & Closed-type \\
\hline 8 & KR-C (Kopen) & Closed-type \\
\hline 9 & KR-C2 (Kromondangsan) & Closed-type \\
\hline 10 & KR-C0 (Lumbungrejo) & Closed-type \\
\hline 11 & KR-C1 (Ngentak) & Closed-type \\
\hline 12 & KR-C2 (Jlopo) & Closed-type \\
\hline 13 & KR-C3 (Jlopo) & Closed-type \\
\hline 14 & KR-C4 (Jlapan) & Closed-type \\
\hline 15 & KR-C5 (Jlapan) & Closed-type \\
\hline 16 & KR-C6 (Mlesen) & Closed-type \\
\hline 17 & KR-C7 (Mlesen) & Open-type (Conduit) \\
\hline 18 & KR-C8 (Mlesen) & Closed-type \\
\hline 19 & KR-C11 (Bakalan) & Closed-type \\
\hline 20 & KR-C12 (Bakalan) & Closed-type \\
\hline 21 & KR-C13 (Bakalan) & Closed-type \\
\hline 22 & KR-GS DS Mataram Syphon & Closed-type \\
\hline 23 & KR-C (Blaburan) & Closed-type \\
\hline & &
\end{tabular}

Kegiatan survey bangunan sabo dam di wilayah sungai Krasak dikelompokkan berdasarkan kondisi jalan isnpeksi, kondisi aliran sungai, aktivitas penambangan, kondisi sedimen, dan kondisi kerusakan. Hasil dari survey dapat dilihat pada Gambar 2.

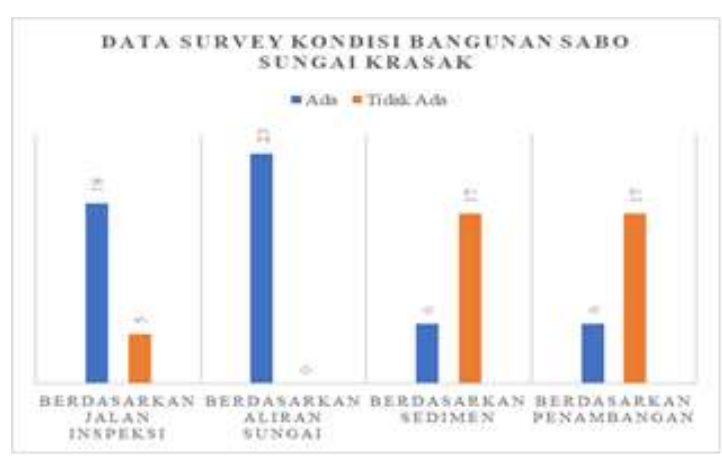

Gambar 2. Data survey bangunan Sabo Sungai Krasak 
Selanjutnya berdasarkan data hasil survey dan data sekunder yang diperoleh tahap analisis dilakukan lebih lanjut dengan membuat skala kerusakan seperti terlihat pada Tabel 5.

Tabel 5. Kriteria penilaian kerusakan bangunan [5]

\begin{tabular}{l|c}
\hline \multicolumn{1}{c|}{ Kondisi } & Nilai Kerusakan (\%) \\
\hline Baik & $<10 \%$ \\
\hline Rusak Ringan & $10 \%-20 \%$ \\
\hline Rusak Sedang & $20 \%-40 \%$ \\
\hline Rusak Berat & $>40 \%$ \\
\hline
\end{tabular}

Bangunan Sabo dam adalah salah satu bangunan pengendali lahar yang berfungsi menahan sedimen akibat banjir lahar dingin, sehingga kriteria penilaian kerusakan dengan bobot terbesar adalah berkaitan dengan sedimen di sekitar bangunan. Adapun deskripsi masing-masing kondisi kerusakan adalah sebagai berikut:

1. Kondisi baik.

Kondisi baik ditunjukan dengan kondisi sedimen yang tidak penuh (rata dengan mercu) dan kondisi sabo hanya perlu dilakukan pemeliharaan rutin seperti babat rumput.

2. Kondisi Rusak Ringan

Kondisi rusak ringan ditunjukan dengan kondisi kondisi sedimen yang tidak penuh (rata dengan mercu), hanya diperlukan pemeliharaan rutin seperti babat rumput, dan akses sekitar bangunan perlu dilakukan perbaikan.

3. Kondisi Rusak Sedang

Kondisi rusak sedang ditunjukan dengan kondisi sedimen telah penuh (rata dengan mercu) dan terjadi kerusakan di beberapa bagian tubuh sabo atau terjadi gerusan pada lantai/apron.

4. Kondisi Rusak Berat

Kondisi rusak berat ditunjukan dengan kondisi sabo yang sudah tidak dapat teridentifikasi bagian-bagiannya, sehingga perlu dilakukan rekonstruksi pada bangunan tersebut.

Berikut adalah contoh foto dokumentasi bangunan sabo dam di sungai Krasak berdasarkan kondisi kerusakannya.

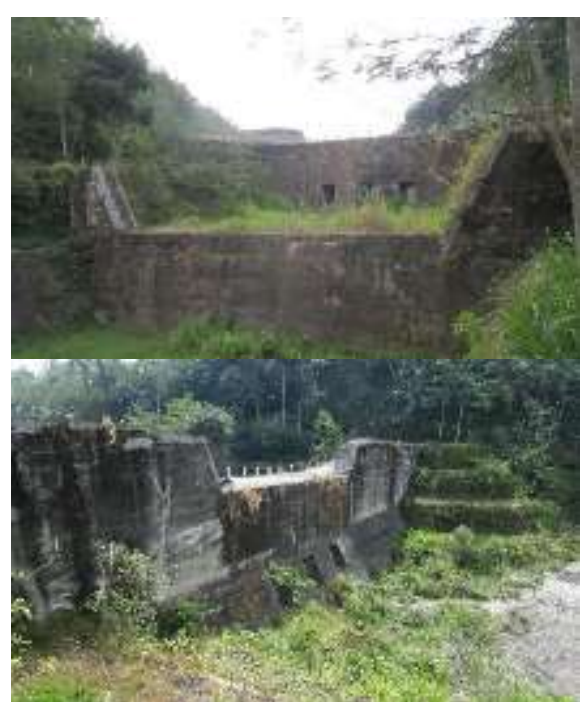

Gambar 3. Contoh Sabo Dam kondisi baik



Gambar 4. Contoh Sabo Dam kondisi rusak ringan

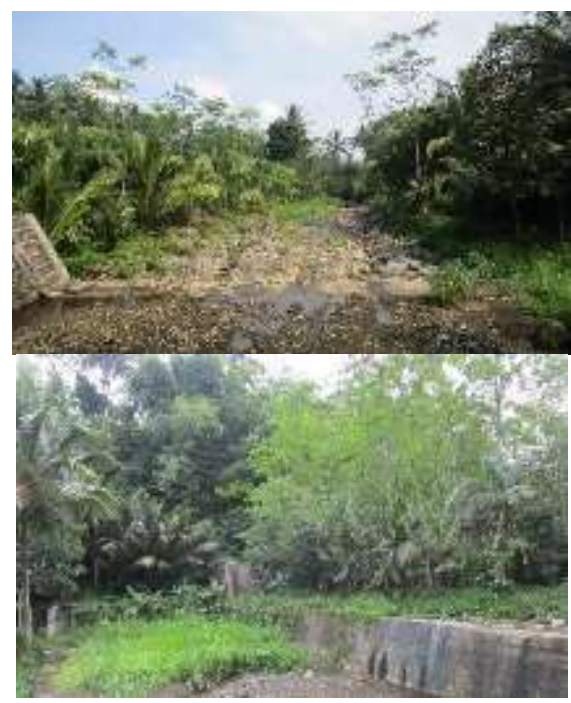

Gambar 5. Contoh Sabo Dam kondisi rusak sedang 
Hasil penilaian pada bangunan sabo di sungai Krasak sejumlah 23 bangunan dapat dilihat pada Tabel 6.

Tabel 6. Peniilaian kerusakan bangunan Sabo di Sungai Krasak

\begin{tabular}{|c|c|c|c|}
\hline $\begin{array}{l}\mathbf{N} \\
\mathbf{0}\end{array}$ & Nama & $\begin{array}{c}\% \\
\text { Kerusak } \\
\text { an }\end{array}$ & $\begin{array}{c}\text { Kriteria } \\
\text { Kerusak } \\
\text { an }\end{array}$ \\
\hline 1 & $\begin{array}{l}\text { KR-D5 } \\
\text { (Tunggul } \\
\text { Arum) }\end{array}$ & 8.08 & Baik \\
\hline 2 & BD RD1 & 6.44 & Baik \\
\hline 3 & $\begin{array}{l}\text { KR-D3 } \\
\text { (Gondoarum) }\end{array}$ & 13.65 & Ringan \\
\hline 4 & $\begin{array}{l}\text { KR-C } \\
\text { (Gedoyo) }\end{array}$ & 23.65 & Sedang \\
\hline 5 & $\begin{array}{l}\text { KR-C } \\
\text { (Kembang) }\end{array}$ & 10.87 & Ringan \\
\hline 6 & $\begin{array}{l}\text { KR-C } \\
\text { (Kranggan) }\end{array}$ & 16.44 & Ringan \\
\hline 7 & $\begin{array}{l}\text { KR-C3 } \\
\text { (Kranggan) }\end{array}$ & 8.75 & Baik \\
\hline 8 & KR-C (Kopen) & 13.75 & Ringan \\
\hline 9 & $\begin{array}{l}\text { KR-C2 } \\
\text { (Kromondangs } \\
\text { an) }\end{array}$ & 6.83 & Baik \\
\hline 10 & $\begin{array}{l}\text { KR-C0 } \\
\text { (Lumbungrejo) }\end{array}$ & 11.06 & Ringan \\
\hline 11 & $\begin{array}{l}\text { KR-C1 } \\
\text { (Ngentak) }\end{array}$ & 15.87 & Ringan \\
\hline 12 & KR-C2 (Jlopo) & 8.46 & Baik \\
\hline 13 & KR-C3 (Jlopo) & 10.1 & Ringan \\
\hline 14 & KR-C4 (Jlapan) & 13.56 & Ringan \\
\hline 15 & KR-C5 (Jlapan) & 11.92 & Ringan \\
\hline 16 & $\begin{array}{l}\text { KR-C6 } \\
\text { (Mlesen) }\end{array}$ & 10.1 & Ringan \\
\hline 17 & $\begin{array}{l}\text { KR-C7 } \\
\text { (Mlesen) }\end{array}$ & 12.79 & Ringan \\
\hline 18 & $\begin{array}{l}\text { KR-C8 } \\
\text { (Mlesen) }\end{array}$ & 9.52 & Baik \\
\hline 19 & $\begin{array}{l}\text { KR-C11 } \\
\text { (Bakalan) }\end{array}$ & 7.98 & Baik \\
\hline 20 & $\begin{array}{l}\text { KR-C12 } \\
\text { (Bakalan) }\end{array}$ & 9.81 & Baik \\
\hline 21 & $\begin{array}{l}\text { KR-C13 } \\
\text { (Bakalan) }\end{array}$ & 15.29 & Ringan \\
\hline 22 & $\begin{array}{l}\text { KR-GS DS } \\
\text { Mataram } \\
\text { Syphon }\end{array}$ & 9.35 & Baik \\
\hline 23 & $\begin{array}{l}\text { KR-C } \\
\text { (Blaburan) }\end{array}$ & 4.62 & Baik \\
\hline
\end{tabular}

Hasil analisis menunjukkan bahwa kondisi bangunan sabo di wilayah sungai Krasak rata-rata masih dalam kondisi baik dan hanya 1 bangunan yang mengalami rusak sedang sehingga perlu dilakukan rehabilitasi. Untuk 22 bangunan yang lain hanya diperlukan pemeliharaan rutin untuk menjaga adar bangunan tersebut dapat berfungsi dengan baik. Berdasarkan hasil tersebut maka dapat disimpulkan bahwa bangunan Sabo di sungai Krasak masih dalam kondisi baik dan dapat masih dapat berfungsi sebagai pengendali sedimen.

\section{KESIMPULAN DAN SARAN \\ 5.1 Kesimpulan}

Berdasarkan hasil penelitian yang telah dilakukan, sesuai fungsi utama bangunan Sabo dam sebagai bangunan pengendali lahar yang berfungsi menahan sedimen akibat banjir lahar dingin diketahui bahwa KR-C Gedoyo adalah bangunan sabo dengan kondisi kerusakan paling parah yaitu sebesar 23,65\%. Selain bangunan sabo, terdapat bangunan pengendali sedimen lainnya seperti cekdam dan groundsill. Akan tetapi bangunan cekdam dan groundsill termasuk ke dalam bangunan prasarana sungai sehingga tidak termasuk dalam objek penelitian yang dilakukan.

\subsection{Saran}

Dilihat dari hasil yang telah disebutkan, peneliti mempunyai saran sebagai berikut:

1. Kegiatan operasi dan pemeliharaan pada bangunan sabo hendaknya terintegrasi antar bangunan yang berada pada 1 alur sungai karena adanya efek domino yang akan ditumbulkan.

2. Hendaknya segera dilakukan kegiatan pemeliharaan bangunan dengan nilai kerusakan $>20 \%$ agar fungsi bangunan sabo/pengendali lahar dapat berfungsi dengan baik.

3. Kegiatan pemantauan dan inspeksi rutin sebaiknya dilakukan secara kontinyu agar kondisi bangunan yang ada dapat diketahui update setiap saat

\section{DAFTAR PUSTAKA}

[1] Cahyono, Joko. 2000. Pengantar Teknologi Sabo, Yayasan Sabo Indonesia. Yogyakarta.

[2] Suparman, dkk. (2011). Sabo Untuk Penanggulangan Bencana Akibat Aliran 
Sedimen. Jakarta: Yayasan Air Adhi Eka.

[3] Anonim, 2015. Konsepsi Pengaturan Angka Kebutuhan Nyata Operasi dan Pemeliharaan Prasarana Pengendali Lahar dan Sedimen. Direktorat Jenderal Sumber Daya Air. Jakarta.

[4] Anonim, 2015. Rancangan Pedoman Angka Kebutuhan Nyata Operasi dan Pemeliharaan (AKNOP) Prasarana Pengendali Lahar dan Pengendali Sedimen. Direktorat Jenderal
Sumber Daya Air. Jakarta.

[5] Anonim, 2015. Dirjen Sumber Daya Air BBWS.SO (Pengendalian Lahar G. Merapi). Yogyakarta. 